\title{
Egg Production and Quality of Magelang Duck Fed Diets Containing Different Ratio of Omega 3 : Omega 6 and Organic Zn
}

\author{
A. Darmawan*, K. G. Wiryawan, \& Sumiati \\ Department of Nutrition and Feed Technology, Faculty of Animal Science, Bogor Agricultural University \\ Jln. Agatis, Kampus IPB Darmaga Bogor 16680, Indonesia \\ (Received 23-07-2013; Reviewed 06-09-2013; Accepted 18-11-2013)
}

\begin{abstract}
The aims of this study were to determine the feeding effect of diets containing different ratio of $\omega-3$ and $\omega-6$ fatty acids and organic $\mathrm{Zn}$ on egg production and quality of Magelang duck. A total of 90 ducks of 20 weeks old were randomly divided into 18 experimental units by assigning a completely randomized design with 6 treatments and 3 replications. There were 6 dietary treatments, namely 1 ) ration without palm oil, fish oil and organic $\mathrm{Zn}$ with the ratio of $\omega-3: \omega-6$ was 1: 5 (R0), 2) ration with the ratio of $\omega-3: \omega-6$ was $1: 1.5+200 \mathrm{ppm}$ organic $Z n(R 1), 3)$ ration with the ratio of $\omega-3: \omega-6$ was 1 : $3+200 \mathrm{ppm}$ organic $\mathrm{Zn}(\mathrm{R} 2)$, 4) ration with the ratio of $\omega-3: \omega-6$ was 1: $4.5+200 \mathrm{ppm}$ organic $\mathrm{Zn}$ (R3), 5) ration with the ratio of $\omega-3: \omega-6$ was $1: 6+200 \mathrm{ppm}$ organic $Z n(R 4), 6)$ ration with the ratio of $\omega-3$ : $\omega-6$ was $1: 7.5+200 \mathrm{ppm}$ organic $\mathrm{Zn}$ (R5). Observation was carried out for $9 \mathrm{wk}$. The results showed that the ration containing the ratio of $\omega-3: \omega-6=1: 3$ and organic Zn (R2) produced significantly $(P<0.05)$ the highest egg production and the lowest egg production was resulted by the dietary treatment without oil and organic $\mathrm{Zn}$. Ration containing the ratio of $\omega-3: \omega-6=1: 3$ and organic $\mathrm{Zn}$ (R2) significantly $(P<0.05)$ decreased feed conversion ratio to the lowest value and it was significantly different as compared to R0 and R5. It can be concluded that feeding diet containing $\omega-3$ and $\omega-6$ with the ratio of 1:3 $+200 \mathrm{ppm}$ organic $\mathrm{Zn}$ improves egg production without decreasing egg quality.
\end{abstract}

Key words: egg production, Magelang duck, organic $\mathrm{Zn}, \omega-3$ and $\omega-6$ fatty acids

\section{ABSTRAK}

Penelitian ini bertujuan untuk mengkaji penampilan produksi itik magelang yang diberi ransum dengan imbangan asam lemak omega $3(\omega-3)$ dan omega $6(\omega-6)$ yang berbeda dan penambahan $\mathrm{Zn}$ Organik. Penelitian dilakukan selama 9 minggu menggunakan 90 ekor itik magelang berumur 21 minggu. Penelitian menggunakan rancangan acak lengkap dengan enam perlakuan dan tiga ulangan. Perlakuan yang diberikan adalah: 1) ransum tanpa minyak sawit, minyak ikan, dan Zn organic dengan imbangan $\omega-3: \omega-6=1: 5$ (R0), 2) ransum dengan imbangan $\omega-3: \omega-6=1: 1,5+200 \mathrm{ppm}$ Zn organic (R1), 3) ransum dengan imbangan $\omega-3: \omega-6=1: 3+200 \mathrm{ppm} \mathrm{Zn} \mathrm{organic} \mathrm{(R2),} \mathrm{4)} \mathrm{ransum}$ dengan imbangan $\omega-3: \omega-6=1: 4,5+200 \mathrm{ppm} Z \mathrm{Zn}$ organic (R3), 5) ransum dengan imbangan $\omega-3: \omega-6$ $=1: 6+200 \mathrm{ppm} \mathrm{Zn}$ organic (R4), 6) ransum dengan imbangan $\omega-3: \omega-6=1: 7,5+200 \mathrm{ppm} \mathrm{Zn}$ organic (R5). Hasil penelitian menunjukkan bahwa penggunaan asam lemak $\omega-3: \omega-6$ dengan imbangan $1: 3$ ditambah Zn organik 200 ppm nyata $(P<0.05)$ meningkatkan produksi telur (duck day) dibandingkan dengan ransum tanpa menggunakan minyak dan $\mathrm{Zn}$ serta mampu menurunkan $(\mathrm{P}<0.05)$ nilai konversi ransum dibandingkan R0 dan R5. Kesimpulan penelitian adalah bahwa pemberian asam lemak $\omega-3$ dan $\omega$-6 dengan imbangan 1 : 3 ditambah $\mathrm{Zn}$ organik $200 \mathrm{ppm}$ menghasilkan performa produksi paling baik dan tidak menurunkan kualitas telur itik.

Kata kunci: asam lemak $\omega-3$ dan $\omega-6$, itik Magelang, produksi telur, Zn organic

*Corresponding author:

E-mail: arif_darma79@yahoo.com 


\section{INTRODUCTION}

Duck egg production was lower than laying egg production. In the year 2012, it only supplied about 276,220 tones and it was only $22 \%$ of laying egg production (Directorate General of Animal Production, 2012). Therefore, the existence of laying ducks is not able to play a significant contribution to national economic sector, because their production is still low and fluctuated. Egg production is considered to be affected by factors such as genetic, feed intake, protein and energy (Bozkurt et al., 2012). According to Ismoyowati \& Suswoyo (2011), egg production of conventional-reared laying ducks was only about $26.9 \%-41.3 \%$. However, egg production can be improved from $38.3 \%$ to $48.9 \%$ by improving dietary quality and increasing nutritional availabilities, especially those related to egg formation process. Therefore, feed supplementation with highly available nutrient is suggested to strengthen the way of increasing duck egg production ability.

Recently, $\omega-3$ and $\omega-6$ fatty acids have indicated an important role for brain function and integrity, as well as in the formation and growth of the brain, preventing cardiovascular disease (atherosclerosis and coronary heart disease), cancer, tumors, immune and reproductive function (Hardini et al., 2006). Eicosapentaenoic acid (EPA) and arachidonic acid (AA) are precursors of prostaglandins, prostacycline, thromboxane, and leukotriene. According to Estiasih (2009), eicosapentaenoic acid was synthesized from $\omega-3$ fatty, while arachidonic acid was synthesized from omega- 6 fatty acids. Prostaglandins have an important role in several aspects of reproduction, such as ovulation, estrus and embryo survival (Nava et al., 2011). Eicosapentaenoic acid and arachidonic acid are formed from $\omega-3$ and $\omega-6$ fatty acid through elongation of the carbon chain fatty acids and desaturation (saturation reduction or the addition of fatty acid unsaturation) (Estiasih, 2009).

The use of $\omega-3$ and $\omega-6$ fatty acid on laying ducks ration can be combined with $\mathrm{Zn}$ supplementation. The presence of $\mathrm{Zn}$ is very beneficial to the metabolic transformation of $\omega-3$ and $\omega-6$ fatty acid to prostaglandins that play a role in the reproductive system (Bhowmik et al., 2010). The respective element can also activate the amino peptidase and carboxcypeptidase enzyme to provide sufficient amino acids for egg formation (Bachri et al., 2006). The aim of the research was to evaluate the performance and egg duck quality fed different ratio of $\omega-3$ and $\omega-6$ fatty acid and organic Zn supplementation. The $\omega-3$ fatty acid source was fish oil, while the $\omega-6$ fatty acid source was palm oil.

\section{MATERIALS AND METHODS}

Feed ingredients were obtained from PT. Indofeed Bogor. Ninety birds of Magelang laying ducks of $20 \mathrm{wk}$ old, obtained from Ciampea farm, were raised in cages of $1 \times 1 \times 1 \mathrm{~m}$ in size for nine weeks. The ducks were distributed into a completely randomized design with six treatments and three replications (5 birds each). Dietary treatments applied in the present study were as follows: ration palm oil, fish oil and organic $\mathrm{Zn}$ with ratio of $\omega-3$
$: \omega-6=1: 5$ (R0), ration with the ratio of $\omega-3: \omega-6=1: 1.5$ $+200 \mathrm{ppm}$ organic $\mathrm{Zn}$ (R1), ration with the ratio of $\omega-3$ $: \omega-6=1: 3+200 \mathrm{ppm}$ organic $\mathrm{Zn}(\mathrm{R} 2)$, ration with the ratio of $\omega-3: \omega-6=1: 4.5+200 \mathrm{ppm}$ organic $\mathrm{Zn}(\mathrm{R} 3)$, ration with the ratio of $\omega-3: \omega-6=1: 6+200 \mathrm{ppm}$ organic Zn (R4), ration with the ratio of $\omega-3: \omega-6=1: 7.5+200$ ppm organic Zn (R5). Experimental diets were formulated with protein and energy contents of $13 \%-14 \%$ and $2660.75-2905.80 \mathrm{kcal} / \mathrm{kg}$ respectively with the different of $\omega-3$ and $\omega-6$ fatty acid (Table 1). Egg weight and egg production were recorded daily, consumption and feed conversion ratio were recorded weekly. Haugh unit, egg index, egg shell weight, egg shell thickness, yolk weight, albumen weight, and yolk color were measured using all egg samples of one day production at the end of week $2,4,6,8$, and 9 . The data were subjected to analysis of variance, and when significant effect at treatment was found, Duncan's Multiple Range Test was used to determine the significant difference among mean values.

\section{RESULTS AND DISCUSSION}

Based on Table 2, duck fed R5 consumed feed of $156.02 \mathrm{~g} /$ duck/d. Whereas treatment used palm oil and fish oil (R2, R3, and R4) resulted feed consumption $160.53 \mathrm{~g} /$ duck/d, $157.08 \mathrm{~g} / \mathrm{duck} / \mathrm{d}$ and $160.50 \mathrm{~g} / \mathrm{duck} / \mathrm{d}$, respectively. Ration without oil (R0) decreased feed consumption significantly $(\mathrm{P}<0.05)$ by $143.81 \mathrm{~g} / \mathrm{bird} / \mathrm{d}$ compared to R1, R2, R3, and R4 but did not different compared to R5. Ration without oil (R0) had dusty texture that reduce in feed palatability. Ferket \& Gernat (2006) stated that feed intake was influenced by the shape of rations, color and ration palatability.

The average of eggs production for nine weeks (21$29 \mathrm{wk}$ of age) can be seen in Table 2. Rations containing the ratio of $\omega-3: \omega-6=1: 3$ and organic Zn (R2) produced significantly $(\mathrm{P}<0.05)$ highest egg production and the lowest egg production was resulted by the dietary treatment without oil and organic zink (Table 2). This showed that ratio of $\omega-3: \omega-6=1: 3$ produced ideal ratio of arachidonic acid and eicosapentaenoic acid (AA/EPA). Arachidonic acid and eicosapentaenoic acid ratio will be determined by the balance of eicosanoids. Eicosanoids from EPA has competitive action with eicosanoids from AA. Therefore, the activity of eicosanoids in the body is determined by the ratio of AA / EPA (Rizzo et al., 2012). The ratio of $\omega-3: \omega-6=1: 3$ (R2) to be able to produce the ideal ratio of AA / EPA in the body for resulting in optimal performance. One of the eicosanoid is prostaglandin that plays a role in reproduction. Prostaglandins increase the secretion of follicle stimulating hormone (FSH) and luteinizing hormone (LH) from the anterior pituitary. The follicle stimulating hormone will stimulate the follicle growth, while the luteinizing hormone will stimulate the ovulation process (Yuwanta, 2004). The other hand, Bachri et al. (2006) reported that the used of $112.5 \mathrm{mg} \mathrm{Zn}$ increased egg production significantly because the $\mathrm{Zn}$ mineral can activate amino peptidase and carboxcypeptidase enzymes and provide sufficient amino acids for the formation of the egg.

Feed conversion of the ducks in the present study was similar with the finding of Indarsih \& Tamsil 
Table 1. Composition of the experimental diet and calculated nutrient contents

\begin{tabular}{|c|c|c|c|c|c|c|}
\hline \multirow{2}{*}{ Composition } & \multicolumn{6}{|c|}{ Treatment } \\
\hline & R0 & $\mathrm{R} 1$ & $\mathrm{R} 2$ & $\mathrm{R} 3$ & $\mathrm{R} 4$ & R5 \\
\hline \multicolumn{7}{|l|}{ Feed ingredients } \\
\hline Yellow corn (\%) & 68.7 & 44.5 & 45.7 & 47 & 47.2 & 46 \\
\hline Rice bran (\%) & 3.5 & 24 & 22.5 & 21 & 21 & 20.5 \\
\hline Soybean meal (\%) & 13 & 10.7 & 12 & 12.7 & 11 & 12 \\
\hline Fish meal (\%) & 7 & 8 & 7 & 7 & 8 & 9 \\
\hline Palm oil (\%) & 0 & 0 & 3.2 & 4 & 4.6 & 5 \\
\hline Fish oil (\%) & 0 & 5 & 1.8 & 1 & 0.4 & 0 \\
\hline $\mathrm{CaCO}_{3}(\%)$ & 7 & 7 & 7 & 6.5 & 7 & 6.7 \\
\hline $\mathrm{NaCl}(\%)$ & 0.2 & 0.2 & 0.2 & 0.2 & 0.2 & 0.2 \\
\hline Premix (\%) & 0.5 & 0.5 & 0.5 & 0.5 & 0.5 & 0.5 \\
\hline DL-Methionin (\%) & 0.1 & 0.1 & 0.1 & 0.1 & 0.1 & 0.1 \\
\hline Organic Zn (ppm) & 0 & 200 & 200 & 200 & 200 & 200 \\
\hline \multicolumn{7}{|l|}{ Nutrient contents (as fed) } \\
\hline Crude protein $(\%)^{*}$ & 13.31 & 13.66 & 13.45 & 14.26 & 14.20 & 13.88 \\
\hline $\operatorname{ME}(\mathrm{kcal} / \mathrm{kg})^{* *}$ & 2766.60 & 2878.25 & 2660.75 & 2905.80 & 2772.40 & 2786.18 \\
\hline Calcium (\%) & 3.11 & 3.22 & 3.16 & 3.01 & 3.22 & 3.17 \\
\hline Phosphorus avialable (\%) & 0.43 & 0.6 & 0.56 & 0.55 & 0.59 & 0.62 \\
\hline Fiber $(\%)^{*}$ & 3.18 & 4.72 & 4.21 & 3.74 & 4.1 & 4.19 \\
\hline Fat $(\%) *$ & 4.24 & 7.63 & 7.09 & 8 & 8.76 & 8.07 \\
\hline Linoleic acid (\%) & 1.44 & 1.97 & 2.21 & 2.29 & 2.38 & 2.39 \\
\hline Linolenic acid (\%) & 0.28 & 1.32 & 0.75 & 0.5 & 0.39 & 0.32 \\
\hline Linolenic acid : Linoleic acid & $1: 5$ & $1: 1.5$ & $1: 3$ & $1: 4.5$ & $1: 6$ & $1: 7.5$ \\
\hline Lysine (\%) & 0.99 & 0.98 & 0.98 & 0.98 & 0.98 & 1.03 \\
\hline Methionine (\%) & 0.46 & 0.47 & 0.46 & 0.46 & 0.46 & 0.46 \\
\hline Methionine + Cystine (\%) & 0.71 & 0.70 & 0.70 & 0.71 & 0.71 & 0.73 \\
\hline
\end{tabular}

Note: $\mathrm{R} 0=$ ration palm oil, fish oil and organic $Z n$ with ratio of $\omega-3: \omega-6=1: 5 ; \mathrm{R} 1=$ ration with the ratio of $\omega-3: \omega-6=1: 1.5+200$ ppm organic $Z n ; R 2=$ ration with the ratio of $\omega-3: \omega-6=1: 3+200$ ppm organic $Z n ; R 3=$ ration with the ratio of $\omega-3: \omega-6=1: 4.5+200$ ppm organic $Z n ; R 4=$ ration with the ratio of $\omega-3: \omega-6=1: 6+200$ ppm organic $Z n ; R 5=$ ration with the ratio of $\omega-3: \omega-6=1: 7.5+200$ ppm organic $Z n$

* Laboratory of Research Center for Bioresources and Biotechnology, Bogor Agricultural University

** Laboratory of Feed and Technology, Faculty of Animal Science, Bogor Agricultural University

Table 2. Average of feed consumption, egg production and feed conversion ratio of Magelang ducks fed diets containing different ratio of omega 3 : omega 6 and organic $\mathrm{Zn}$

\begin{tabular}{|c|c|c|c|c|c|c|}
\hline \multirow{2}{*}{ Variables } & \multicolumn{6}{|c|}{ Treatment } \\
\hline & $\mathrm{R} 0^{1)}$ & R1 & $\mathrm{R} 2$ & R3 & R4 & $\mathrm{R} 5$ \\
\hline Consumption (g/duck)* & $143.81 \pm 9.43^{a}$ & $153.02 \pm 4.32^{\mathrm{ab}}$ & $160.53 \pm 1.24^{b}$ & $157.08 \pm 1.05^{\mathrm{b}}$ & $160.50 \pm 11.42^{b}$ & $156.68 \pm 1.08^{b}$ \\
\hline Egg production $(\% \mathrm{dd})^{*}$ & $35.08 \pm 3.82^{\mathrm{a}}$ & $46.98 \pm 5.93^{b}$ & $58.47 \pm 5.83^{c}$ & $47.72 \pm 6.85^{\mathrm{b}}$ & $45.52 \pm 6.58^{\mathrm{ab}}$ & $38.31 \pm 4.77^{\mathrm{ab}}$ \\
\hline Feed conversion ratio* & $7.61 \pm 1.01^{\mathrm{c}}$ & $5.55 \pm 0.77^{\mathrm{a}}$ & $5.12 \pm 0.54^{\mathrm{a}}$ & $6.32 \pm 0.28^{\mathrm{ab}}$ & $6.31 \pm 0.51^{\mathrm{ab}}$ & $7.40 \pm 0.69^{\mathrm{bc}}$ \\
\hline
\end{tabular}

Note: R0= ration palm oil, fish oil and organic Zn with ratio of $\omega-3: \omega-6=1: 5$; R1= ration with the ratio of $\omega-3: \omega-6=1: 1.5+200$ ppm organic Zn; R2= ration with the ratio of $\omega-3: \omega-6=1: 3+200$ ppm organic $Z n ; R 3=$ ration with the ratio of $\omega-3: \omega-6=1: 4.5+200$ ppm organic Zn; R4= ration with the ratio of $\omega-3: \omega-6=1: 6+200$ ppm organic Zn; R5= ration with the ratio of $\omega-3: \omega-6=1: 7.5+200$ ppm organic Zn. Means in the same raw with different superscript differ significantly $(\mathrm{P}<0.05)$.

(2012) who reported the conversion ratio of duck ration containing $20 \%$ duckweed and given in the form of dry mash at 24 wk of age was 5.31-7.65. Feed conversion ratio was significantly $(\mathrm{P}<0.05)$ affected by treatments.
The lowest feed conversion was found in group of R2 (Table 2). Ration containing the ratio of $\omega-3: \omega-6=1: 3$ and organic $\mathrm{Zn}(\mathrm{R} 2)$ significantly $(\mathrm{P}<0.05)$ decreased feed conversion ratio to the lowest value and it was 


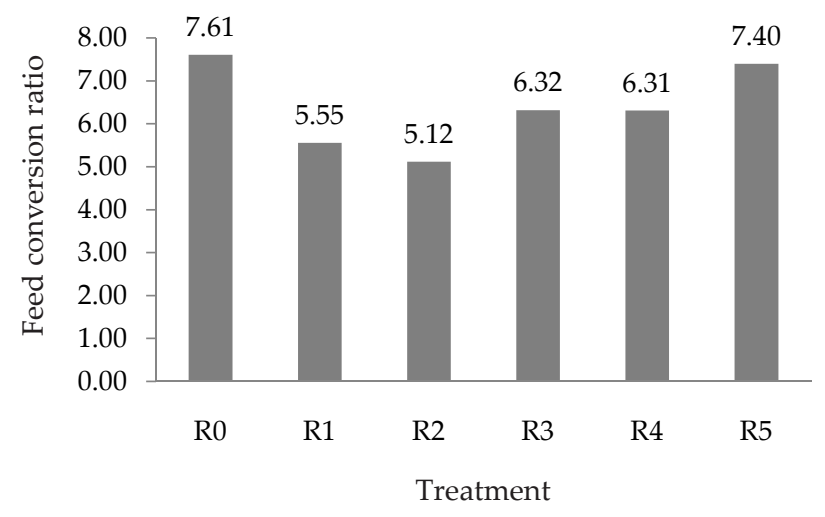

Figure 1. Average of feed conversion ratio (g feed/g egg) of Magelang laying duck fed experimental diets, $\mathrm{R} 0=$ ration palm oil, fish oil and organic $\mathrm{Zn}$ with ratio of $\omega-3$ $: \omega-6=1: 5 ; \mathrm{R} 1=$ ration with the ratio of $\omega-3: \omega-6=1$ $: 1.5+200$ ppm organic $\mathrm{Zn} ; \mathrm{R} 2=$ ration with the ratio of $\omega-3: \omega-6=1: 3+200$ ppm organic Zn; R3= ration with the ratio of $\omega-3: \omega-6=1: 4.5+200$ ppm organic $\mathrm{Zn}$; $\mathrm{R} 4=$ ration with the ratio of $\omega-3: \omega-6=1: 6+200$ ppm organic $Z n ; R 5=$ ration with the ratio of $\omega-3: \omega-6$ $=1: 7.5+200$ ppm organic Zn.

significantly different as compared to R0 and R5. The ratio of $\omega-3$ and $\omega-6$ fatty acid in $R 2$ might achieve an ideal condition for egg production. According to Leeson \& Summers (2005), factors that affect feed conversion are eggs production, energy and nutrient content of the feed, body weight, and temperature.

The average egg weight in the study was $56.60 \mathrm{~g}$. It was lower than the finding of Nugraha et al. (2013) who reported that egg weight of ducks reared at dry cage enclosure was $72.330 \pm 4.363 \mathrm{~g}$. The difference was possibly due to the low protein consumption. Protein consumption in the present study was about $22.89 \mathrm{~g} / \mathrm{bird} / \mathrm{d}$, while Ketaren \& Prasetyo (2002) stated that protein consumption on 20-43 wk of age was $26.65 \mathrm{~g} / \mathrm{bird} / \mathrm{d}$. According to Leeson \& Summers (2005), protein and/or amino acids (especially methionine) are the most nutrients that have important role in controlling the size of eggs. Other aspect supported such about phenomenon was stated by Mahmood \& Al-Daraji (2011) that metalloenzyme such as thymidine kinase enzyme containing $\mathrm{Zn}$ is suggested to take a part of role in egg formation. Fish oil in the diet did not affect egg size but affect the composition of the fat content in the yolk (Suripta \& Astuti, 2006).

The treatments did not affect haugh unit value. The average of haugh unit in this study was 94.87 (Table 3). That showed the used of palm oil, fish oil and organic Zn did not effect haugh unit. Haugh unit values were categorized as AA quality eggs. Haugh unit values more than 72 are categorized as AA quality eggs (Yuwanta, 2004).). Haugh unit values were greatly influenced by storage time and temperature of the environment (Roberts, 2004). The measurement of HU in this study was conducted at the same storage period and temperature $\left( \pm 24 \mathrm{~h}\right.$ at a temperature of $\left.27-28^{\circ} \mathrm{C}\right)$, so they were similar.

There were not significant differences for albumens weight. The average of albumens weight was $31.74 \mathrm{~g}$ (55.99\%). That showed the used of palm oil, fish oil and organic $\mathrm{Zn}$ did not affect albumen weight. The egg weight in this study was not different. Albumen weight is generally influenced by egg weight (Rajkumar et al., 2009). The average of albumens weight in this research were lower than reported by Nugraha et al.(2013) that albumen weight was $36.90 \mathrm{~g}$

The treatments did not affect yolk weight. That showed the used of palm oil, fish oil and organic Zn did not affect the yolk weight. The average of yolk weight was $17.45 \mathrm{~g}$ (Table 3). According to Bell \& Weaver (2002), the yolk percentage was around 30\%-32\% of egg weight. As proposed by Rajkumar et al. (2009) that egg size is more related to the size of the yolk compared with albumen, despite the fact that the albumin is still important to determine the size of an egg. According to Subekti et al. (2006), decreased yolk cholesterol levels can decrease yolk weight.

Table 3. The egg quality of ducks fed diets containing different ratio of omega 3 : omega 6 and organic Zn

\begin{tabular}{|c|c|c|c|c|c|c|}
\hline \multirow{2}{*}{ Variables } & \multicolumn{6}{|c|}{ Treatment } \\
\hline & $\mathrm{R} 0^{1)}$ & R1 & $\mathrm{R} 2$ & R3 & $\mathrm{R} 4$ & R5 \\
\hline Egg weight (g) & $53.66 \pm 1.09$ & $57.58 \pm 3.31$ & $57.84 \pm 0.34$ & $57.84 \pm 0.96$ & $56.85 \pm 0.43$ & $56.16 \pm 3.74$ \\
\hline Egg yolk score & $11.27 \pm 0.21$ & $11.32 \pm 0.16$ & $11.22 \pm 0.10$ & $11.22 \pm 0.31$ & $11.30 \pm 0.17$ & $11.20 \pm 0.12$ \\
\hline Haugh unit & $94.50 \pm 0.49$ & $93.95 \pm 2.60$ & $93.86 \pm 1.65$ & $93.86 \pm 2.49$ & $95.71 \pm 2.86$ & $97.38 \pm 3.48$ \\
\hline Albumen weight (g) & $30.37 \pm 0.70$ & $31.82 \pm 2.63$ & $32.32 \pm 1.10$ & $32.32 \pm 0.65$ & $31.76 \pm 0.27$ & $31.85 \pm 2.39$ \\
\hline Albumen weight (\%) & $56.62 \pm 1.86$ & $55.21 \pm 1.39$ & $55.88 \pm 1.59$ & $55.88 \pm 1.54$ & $55.86 \pm 0.17$ & $56.70 \pm 0.77$ \\
\hline Yolk weight (g) & $16.98 \pm 1.24$ & $18.14 \pm 1.41$ & $17.67 \pm 1.99$ & $17.67 \pm 1.17$ & $17.85 \pm 1.20$ & $16.34 \pm 2.12$ \\
\hline Yolk weight (\%) & $31.64 \pm 1.80$ & $31.64 \pm 3.96$ & $30.56 \pm 3.49$ & $30.56 \pm 1.63$ & $31.40 \pm 2.18$ & $29.27 \pm 4.99$ \\
\hline Eggshell weight (g) & $6.30 \pm 0.20$ & $6.62 \pm 0.24$ & $6.55 \pm 0.11$ & $6.55 \pm 0.05$ & $6.67 \pm 0.18$ & $6.41 \pm 0.34$ \\
\hline Eggshell weight (\%) & $11.74 \pm 0.15$ & $11.50 \pm 0.26$ & $11.32 \pm 0.14$ & $11.32 \pm 0.22$ & $11.73 \pm 0.30$ & $11.41 \pm 0.23$ \\
\hline Eggshell thickness (mm) & $0.47 \pm 0.01$ & $0.47 \pm 0.01$ & $0.47 \pm 0.02$ & $0.47 \pm 0.02$ & $0.48 \pm 0.02$ & $0.47 \pm 0.01$ \\
\hline
\end{tabular}

Note: $\mathrm{R} 0=$ ration palm oil, fish oil and organic Zn with ratio of $\omega-3: \omega-6=1: 5$; $\mathrm{R} 1=$ ration with the ratio of $\omega-3: \omega-6=1: 1.5+200$ ppm organic $Z \mathrm{n}$; $\mathrm{R} 2=$ ration with the ratio of $\omega-3: \omega-6=1: 3+200$ ppm organic $Z n ; R 3=$ ration with the ratio of $\omega-3: \omega-6=1: 4.5+200$ ppm organic $Z$ n; R4= ration with the ratio of $\omega-3: \omega-6=1: 6+200$ ppm organic Zn; R5= ration with the ratio of $\omega-3: \omega-6=1: 7.5+200$ ppm organic Zn. 
The treatments did not affect eggshell weight. The average of eggshell weight was $6.51 \mathrm{~g}(11.50 \%)$. That showed the used of palm oil, fish oil and organic $\mathrm{Zn}$ did not affect the eggshell weight. Bell \& Weaver (2002) stated that the percentage of eggshell was around 10\%$12 \%$ of egg weight. The absence of treatment effects on eggshell weight was caused by the similarity of protein, energy, Ca, and $\mathrm{P}$ in the ration and the addition of 200 ppm organic Zn did not suppress Ca content in the shell. According to Kebreab et al. (2009), the content of Ca in the feed can affect the eggshell weight and eggshell thickness. Egg shell quality can be influenced by many factors including mineral nutrition. Calcium, magnesium and phosphorus are major inorganic constituents of avian eggshells (King'ori, 2011). Namra et al. (2009) stated that reduction in shell weight can be influenced by the antagonism between the high level of dietary $\mathrm{Zn}$ and $\mathrm{Ca}$.

The treatments did not affect the eggshell thickness. The average of eggshell thickness in this study was 0.47 $\mathrm{mm}$ (Table 3). That showed the used of palm oil, fish oil and organic Zn did not affect the eggshell thickness. Nugraha et al. (2013) who reported that eggshell thickness of ducks reared at dry cage enclosure was between 0.34-0.47 $\mathrm{mm}$. This situation indicates that the use of 200 ppm organic $\mathrm{Zn}$ in the diet did not show adverse effects on the formation of eggshell thickness. The addition of 200 ppm organic $\mathrm{Zn}$ did not suppress the mineral content of calcium in the eggshell. According to Leeson \& Summers (2005), the main nutrients that affect the eggshell thickness are calcium, phosphorus and vitamin D3. The content of $\mathrm{Ca}$ and $\mathrm{P}$ in the diet contributes to the quality of the egg shell because of the egg shell formation need carbonate ion and $\mathrm{Ca}$ ion to form $\mathrm{CaCO}_{3}$ in eggshell. According to Kebreab et al. (2009), the higher of the calcium intake can improve quality of the egg shell.

The treatments did not affect yolk score. Yolk color is influenced by xanthophylls in the feed. If the feed contains more xanthophylls the color of the yolk is orange red (Castaneda et al., 2005). Yellow corn has content of xanthophylls approximately $20 \mathrm{mg} / \mathrm{kg}$ (Leeson \& Summers, 2005), while palm oil also has a high $\beta$-carotene approximately $780 \mathrm{mg} / \mathrm{kg}$ (Mustapa et al., 2011). The ration in R0 used $68 \%$ yellow corn resulted 11.3 score of egg yolk color. Rations in R1, R2, R3, R4, and R5 used 44.5 to $47.2 \%$ yellow corn also had score that were not significantly different from R0. This shows that the content of xanthophylls (tunaxantin, lutein, and zeaxantin) in fish oil and $\beta$-carotene in palm oil could replace the xanthophylls contained in the 20.8\%-23.5\% yellow corn. The color pigment in feed ingredients are xanhtophyl, zeaxanthin, canthaxanthin, astaxanthin, $\beta$ apo-8-carotenoic, cryptoxanthin, and $\beta$-carotene (Leeson \& Summers, 2005).

\section{CONCLUSION}

The use of fish oil and palm oil with proportion of $\omega-3: \omega-6=1: 3$ combined with the addition of $200 \mathrm{ppm}$ organic $\mathrm{Zn}$ can significantly increase the production of duck eggs, reduce feed conversion ratio and do not decrease the physical quality of the eggs.

\section{ACKNOWLEDGEMENT}

This research was funded by Indonesian Ministry of Education and Culture, Directorate General of Higher Education with contract No: 52/IT3.41.2/L1/SPK/2013.

\section{REFERENCES}

Bachri, I., Roeswandy, \& A. Nasution. 2006. Pemanfaatan solid dekanter dan suplementasi mineral Zinkum dalam ransum terhadap produksi burung puyuh (Cortunix-cortunix japonica) umur 6-17 minggu dan daya tetas. J Agrib Pet. 2:72-77.

Bell, D. D., Jr. \& W. W. Weaver. 2002. Commercial Chicken Meat and Egg Production. $5^{\text {th }}$ ed. Kluwer Academic Publishers, Norwell, MA. http://dx.doi.org/10.1007/978-1-4615-0811-3

Bhowmik, D., Chiranjib, \& K. P. Kumar. 2010. A Potential medicala importance of zinc in human health and chronic disease. Int. J. Pharm Biomed Sci. 1:05-11.

Bozkurt, M., K. Küçükyilmaz., M. Pamukçu., M. Çabuk., A. Alçiçek, \& A. U. Çatlıi. 2012. Long-term effects of dietary supplementation with an essential oil mixture on the growth and laying performance of teo layer strains. Ital. J. Anim. Sci. 11: e5. http://dx.doi.org/10.4081/ijas.2012.e5

Castaneda, M. P., E. M. Hirschler, \& A. R. Sams. 2005. Skin pigmentation evaluation in broilers fed natural and synthetic pigments. Poult Sci. 84:143-147. http://dx.doi.org/10.1093/ ps/84.1.143

Directorate General of Livestock Production. 2012. Livestock Statistics Book. Ministry of Agriculture, Jakarta.

Estiasih, T. 2009. Minyak Ikan: Teknologi dan Penerapannya untuk Pangan dan Kesehatan. Graha Ilmu, Jogjakarta.

Ferket, P. R. \& A. G. Gernat. 2006. Factors that affect feed intake of meat birds. Int. J. Poult. Sci. 5: 905-911. http://dx.doi. org/10.3923/ijps.2006.905.911

Hardini, D., T. Yuwanta, Zuprizal, \& Supadmo. 2006. The change in cholesterol content of long chain fatty acid egg during processing and its influence to the Rattus norvegicus L. blood cholesterol content. JITV 11:260-265.

Indarsih, B. \& M. H. Tamsil. 2012. Feeding diets containing different forms of duckweed on productive performance and egg quality of ducks. Med Pet. 35: 128-132. http://dx.doi. org/10.5398/medpet.2012.35.2.128

Ismoyowati \& I. Suswoyo. 2011. Produksi telur dan pendapatan itik pada pemeliharaan cara gembala dan terkurung di daerah pertanian dan perikanan. J. Pemb. Pedes. 11: 4554.

King'ori, A. M. 2011. A review of the uses of poultry eggshells and shell membranes. Int. J. Poult. Sci. 10: 908-912. http:// dx.doi.org/10.3923/ijps.2011.908.912

Kebreab. E., J. France,.R. P. Kwakkel., S. Leeson., H. D. Kuhi, \& J. Dijkstra. 2009. Development and evaluation of a dynamic model of calcium and phosphorus flows in layer. Poult Sci. 88:680-68. http://dx.doi.org/10.3382/ps.200800157

Ketaren, P. P. \& L. H. Prasetyo. 2002. Pengaruh pemberian pakan terbatas terhadap produksi telur itik silang Mojosari x Alabio (MA): 1. Masa bertelur fase pertama umur 20-43 minggu. JITV 7: 38-45.

Lesson, S. \& J. D. Summers. 2005. Commercial Poultry Nutrition. $3^{\text {rd }}$ Ed. Department of Animal and Poultry Science, University of Guelph. University Books, Guleph

Mahmood, H. M. \& H. J. Al-Daraji. 2011. Zinc improves egg quality in Cobb500 broiler breeder females. Int. J. Poult. Sci. 10: 471-476. http://dx.doi.org/10.3923/ijps.2011.471.476

Mustapa, A. N., Z. A. Manan., C. Y. Azizi., W. B. Setianto, \& A. K. Omar. 2011. Extraction of b-carotenes from palm oil mesocarp using sub-critical R134a. J. Food. Chem. 125: 262- 
267. http://dx.doi.org/10.1016/j.foodchem.2010.08.042

Namra, M. M. M., H. M. Abdelwahed, \& H. M. Fayek. 2009. Evaluation of different source of dietary zinc supplementation for laying Japanese quail performance, Egypt. Poult Sci. 29:127-143.

Nava, G. H., F. Fatahnia., A. Nikkhah, \& M. J. Zamiri. 2011. Effect of dietary polyunsaturated fatty acid on ovarian function and prostaglandin secretion in lactating dairy cows. Int. J. Vet. Res. 2: 129-135

Nugraha, F. S., M. Mufti, \& I. Hari. 2013. Kualitas telur yang di pelihara secara terkurung basah dan kering di Kabupaten Cirebon. J. Ilmiah Pet 1: 726-734.

Rajkumar, U., R. P. Sharma, K. S. Rajaravinda, \& M. Niranjan. 2009. Effect of genotype and age on egg quality traits in naked neck chicken under tropical climate from india. Int. J. Poult. Sci. 8: 1151-1155. http://dx.doi.org/10.3923/ ijps.2009.1151.1155

Rizzo, A. M., P. A. Corsetto, G. Montorfano, A. Opizzi, M. Faliva, A. Giacosa, G. Ricevuti, C. Pelucchi, B. Berra, \& M. Rondanelli. 2012. Comparison between the AA/EPA ratio in depressed and non depressed elderly females: omega3 fatty acid supplementation correlates with improved symptoms but does not change immunological parameters. Nutrition Journal 11:82. http://dx.doi.org/10.1186/14752891-11-82

Roberts, J. R. 2004. Factors affecting internal quality eggs and egg shell quality in laying hens. J Poult. Sci. 41: 161-177. http://dx.doi.org/10.2141/jpsa.41.161

Suripta H. \& P. Astuti. 2006. Pengaruh penggunaan minyak lemuru dan minyak sawit dalam ransum terhadap rasio asam lemak omega-3 dan omega-6 dalam telur burung puyuh (coturnix coturnix japonica). J Indon Trop Anim. Agric. 32:22-27.

Subekti. S., W. G. Piliang., W. Manalu, \& T. B. Murdiati. 2006. Penggunaan tepung daun katuk dan ekstrak daun katuk (Sauropus androgynus L.Merr) sebagai substitusi ransum yang dapat menghasilkan produk puyuh jepang rendah kolesterol. JITV 11: 254-259.

Yuwanta, T. 2004. Dasar Ternak Unggas. Kanisius, Yogyakarta. 